\title{
Surgical and Non-Surgical Management and Treatment of Glioblastoma: II. Recurring Tumors
}

\author{
Alain L Fymat* \\ International Institute of Medicine \& Science, USA
}

Submission: October 28, 2017; Published: November 16, 2017

*Corresponding author: Alain L Fymat, International Institute of Medicine and Science, California, USA, Tel: (760) 485-9149;

Email: alain.fymat@fiimas.org

\begin{abstract}
Glioblastoma (also known as glioblastoma multiform) is the most common primary brain tumor in adults. It remains an unmet need in oncology. Complementing an earlier discussion of primary and secondary tumors in both cases of monotherapies and combined therapies, Clinical trials and other reported practices will also be discussed and summarized. Regarding chemotherapy, whereas it has historically provided little durable benefit with tumors recurring within several months, for brain tumors, the access is hindered or even forbidden by the presence of the brain protective barriers, chiefly the blood brain barrier. More effective therapies involving other options are required including surgery, conformal radiotherapy, boron neutron therapy, intensity modulated proton beam therapy, antiangiogenic therapy, alternating electric field therapy, ....without neglecting palliative therapies. Research conducted in these and other options is also reviewed to include microRNA, immunotherapy, adjuvant therapy, gene therapy, stem cell therapy, and intra-nasal drug delivery.
\end{abstract}

Abbreviations: BBB: Blood Brain Barrier; BPB: Brain Protective Barriers; DC: Dendritic Cells; EGFR: Epidermal Growth Factor Receptor gene (a pro-angiogenic cytokine); EMA: European Medicines Agency; FDA: (U.S.) Food \& Drug Administration; GB: GlioBlastoma; GBM: GlioBlastoma Multiform; GBSLC: GB Stem-Like Cells; GDV: Gene Delivery Vehicle; GTT: Gene Transfer Technology; INDD: Intra-Nasal Drug Delivery; KPS: Karnofsky Performance Score; MGMT: 06-alkylguanine DNA alkyltransferase; OS: Overall Survival; PET: Positron Emission Tomography; RNA: Ribo-Nucleic Acid; TMZ: Temozolomide (an alkalyting agent used as a treatment of some brain cancers; as a first-line treatment for GBs and as a second-line treatment for astrocytomas) (brand names: Temodar, Temodal and Temcad); TSC: Tumor Stem Cell

Disorders cited: Asthenia; Convulsions; Diarrhea; Fatigue; Fibrosis (renal, hepatic, pulmonary); Glioblastoma; Glioblastoma Multiform; Hematologic Toxicity; Hypertension; Leucopenia;Lymphopenia; Malaria; Migraine; Radionecrosis; Rash; Recurrent Glioblastoma; Skin toxicity; Thrombocytopenia; Thromboembolic events

Drugs mentioned: Afatinib (an irreversible inhibitor of mutated EGFR); Aflibercept; 5-Aminolevulinic Acid (a surgery dye); Antiangiogenics; Bevacizumab (a monoclonal antibody with activity against VEVF); Carboplatin; Carmustine; Cediranib (an angiogenic inhibitor); Celecoxib; Cetuximab; Cilengitide (an inhibitor of integrin $\alpha \mathrm{V} \beta 3$ and $\alpha \mathrm{V} \beta 5$ ); Corticosteroids (including anti-convulsant ones); Cytarabine; Entemustine; Enzasturine; Epidermal Growth Factor Receptor; Ertolinib; Etoposide; Everolimus; Farnesyl transferse antagonist; Fotemustine; Gefitinib; Histone deacetylase antagonist; Irinotecan; Lapatinib (HKI-272); Lomustine; Nimustine; Nitrosoureas; Nivolumab (Opdivo); O6-benzylguanine (agent that induces MGMT depletion); Pembrolizumab (Keytruda); Perillyl Alcohol; Phospholinositide 3-kinase antagonist; Polifeprosan; Procarbazine; Sirolimus (an inhibitor of MTOR) (mammalian target of Rapamycin); Statins; Steroids; Temozolomide; Vincristine.

Keywords: Antiangiogenic Therapy; Bevacizumab; Blood Brain Barrier; Cediranib; Cilengitide; Epidermal Growth Factor Receptor; Glioblastoma; Glioblastoma Multiform; Gliomatosis; MGMT Methylation; Recurrent Glioblastoma; Stem-Like Cancer Cells; Surgery; Temozolomide.

\section{Introduction}

Glioblastoma (also known as glioblastoma multiform) is the most common primary brain tumor in adults. It remains an unmet need in oncology. Figure 1 is a colored positron emission tomography of the brain showing a GB. In a companion article [1], I limited my considerations to primary and secondary tumors and their metastases. I discussed at some length the standard treatment of glioblastoma (GB) consisting of

a. surgery (maximal resection of $\sim />98 \%$ of the tumor) followed by b. radio chemotherapy ( 6 weeks of radiotherapy at a dose of 60 Grey [Gy] together with concomitant chemotherapy with Temozolomide (TMZ) at a rate of $75 \mathrm{mg} / \mathrm{m}^{2}$ daily); and once chemoradiotherapy is complete

c. Adjuvant treatment (a minimum of 6 months with TMZ starting at a dose of $150-200 \mathrm{mg} / \mathrm{m} 2$ for 5 days every 28 days). Chemotherapy by itself that is the use of cytotoxic drugs in isolation or in combination with other drugs, has historically provided little durable benefit as the tumors 
recur within several months. This is more particularly the case for glioblastoma because treatment is hindered, if not precluded, by the presence of the brain protective barriers (BPBs), chiefly the blood brain barrier (BBB). The emphasis in this article is on recurrent GBs (Figure 1).

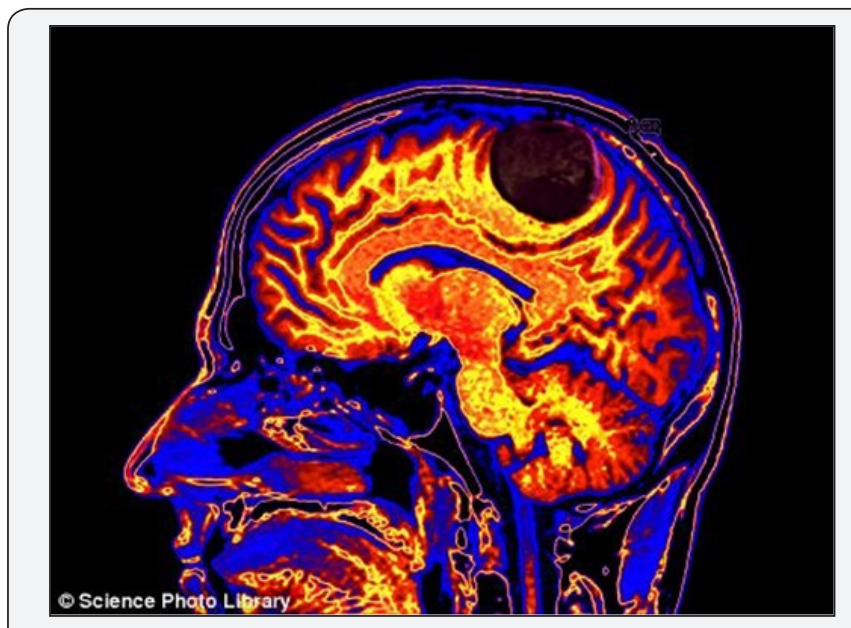

Figure 1: Colored positron emission tomography of the brain.

Most of the above treatments cannot eradicate all tumor cells (surgery is often insufficient given the diffuse nature of the disease; chemotherapy has major limitations because most drugs cannot cross the BBB, and penetration into brain cells is limited). In addition, the cells in brain tumors are greatly heterogeneous, which limits the treatment efficacy and explains the high rate of progression of the disease.

\section{The Case of Recurrent Glioblastomas}

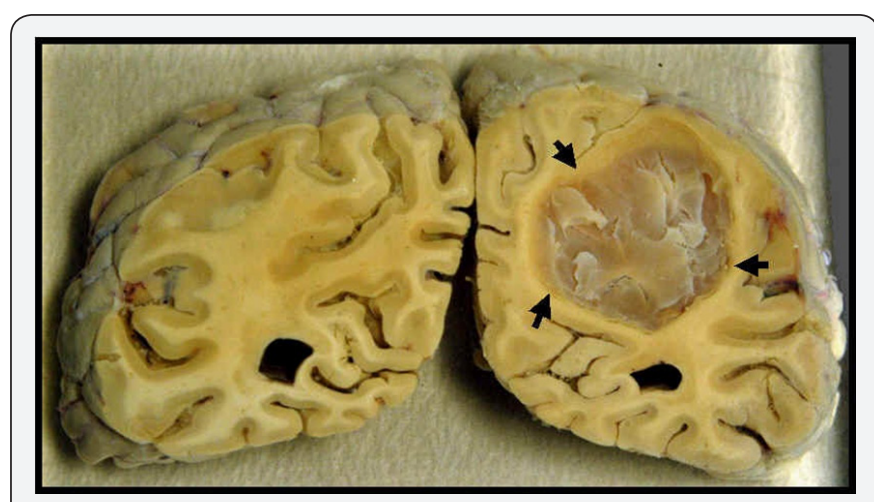

Figure 2 : Excised brain showing glioblastomas.

Disease recurs in almost all patients, and most patients will not be candidates for new surgery or a new course of irradiation so that therapeutic options are limited. Progression-free survival (PFS) after recurrence or progression is $\sim 10$ weeks, and overall survival (OS) is $\sim 30$ weeks. Figure 2 shows an excised brain evidencing the presence of GBs (Figure 2). If the patient's condition allows, the second-line treatment consists of anti-cancer drugs. Other approaches have also been studied, including antiangiogenics, epidermal growth factor receptor (EGFR) inhibitors, nitrosoureas (alkylating agents characterized by high lipophilicity, allowing them to cross the BBB), and retreatment with TMZ. However, a standard second-line therapy has not yet been established.

It must further be emphasized that certain patients will be candidates only for symptomatic treatment because of their poor general condition or co-morbidities. Ensuring appropriate management and support for the complications that typically occur during the course of the disease (convulsions, thrombosis, and cognitive deteriorations) are essential. Currently available medical treatment options for recurrent GB patients will now be reviewed. Figure 3 shows contrast computerized tomography images indicating the presence of GBs.

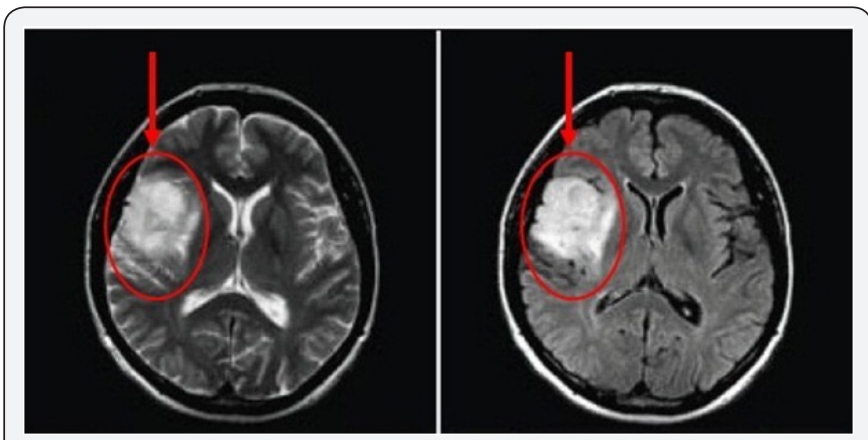

Figure 3 : Contrast computed tomography images of the brain showing a GB.

\section{Surgery}

Approximately only $25 \%$ of patients are considered for surgery after recurrence. However, there are no robust data supporting an increase in survival. Repeat surgery can help to improve symptom control, confirm the diagnosis, and rule out pseudo-progression or radio-necrosis. In certain situations (e.g., total resection), repeat surgery can allow for intralesion chemotherapy with Carmustine wafers (Gliadel: Arbor Pharmaceuticals, Atlanta, GA, U.S.A.), implants for intracranial use that contain Carmustine, a nitrosourea alkylating agent, and Polifeprosan (a biodegradable copolymer that controls release of Carmustine). There are no clinically important adverse reactions related to the Carmustine wafers that have been observed either in the brain or systemically. Interstitial chemotherapy delivered by polymer wafers directly to brain tumors provides a safe and effective treatment for recurrent malignant glioma after repeat intervention.

\section{Re-irradiation}

Although the high radiotherapy dose ( 60 Gy) typically applied in the first-line of treatment to reduce the risk of infield relapse generally hampers use of a second full-dose radiotherapy course, re-irradiation has been shown to increase the survival-lengthening capability of radiation when compared to supportive care only. Re-irradiation can be considered in selected patients with a Karnofsky performance status (KPS) above $60 \%$, a major lesion size below $40 \mathrm{~mm}$, and progression more than 6 months after surgery. The dose most frequently 


\section{Open Access Journal of Surgery}

reported, with or without modulated intensity, falls in the range of 30-60 Gy.

\section{Multiple chemotherapy options}

Multiple chemotherapy options are available for secondline treatment but, owing to discouraging OS results and lower quality of life, no standard of care has been established. Tables 1a-1e below summarize the most relevant trials performed to date with respect to the medical treatment of recurrent GBs. Whether in mono- or combination-therapy, the tables highlight pertinent facts about therapies utilizing the following drug classes: Temozolomide, Nitrosoureas, Antiangiogenics, Epidermal Growth Factor Receptor Gene inhibitors, and a number of other agents, especially those that act on specific molecular targets that have been evaluated in the treatment of recurrent GBs.

Table 1a: Chemotherapy with Temozolomide in mono- and combination-therapy.

\begin{tabular}{|c|c|c|c|c|}
\hline Drug & Agent & Toxicity & $\begin{array}{c}\text { Benefits (PFS-6/Median } \\
\text { OS) }\end{array}$ & Current use \\
\hline $\begin{array}{l}\text { Temozolomide (before } \\
\text { nitrosoureas) } \\
* \text { Metronomic schedules } \\
\text { are superior to the } \\
\text { standard schedule } \\
\text { * Better results for MGMT } \\
\text { patients }\end{array}$ & & Tolerable & $\begin{array}{c}\text { (18-48\%; 5.4-9.9 } \\
\text { months) Median time to } \\
\text { progression: } 21 \text { weeks. } \\
\text { In combination with } \\
\text { radiotherapy } \\
\text { (26-58.\%; 5.1-13 months } \\
\text { (6-27\%; } 3.6 \text { months) }\end{array}$ & $\begin{array}{c}\text { *FIRST LINE: } \\
\text { *Standard treatment: } \\
\text { 150-200 mg/m2 for } 5 \\
\text { days every } 4 \text { weeks. } \\
\text { Extended: } 75-100 \mathrm{mg} / \mathrm{m} 2 \\
\text { daily. } \\
\text { *SECOND LINE: } \\
7 \text { days on, } 7 \text { days off: } 21 \\
\text { days on, } 7 \text { days off } \\
\text { *SECOND LINE \& BASED } \\
\text { ON PROGRESSION: }\end{array}$ \\
\hline \multirow[t]{4}{*}{$\begin{array}{l}\text { Combinations with } \\
\text { Temozolomide } \\
\text { (Do not add any benefit to } \\
\text { Temolozomide alone) }\end{array}$} & Temozolomide+ Sorafenib & Lymphopenia & $(9.4 \%)$ & \\
\hline & Temozolomide+ Celecoxib & & $(43 \%)$ & \\
\hline & $\begin{array}{l}\text { Temozolomide+ } \\
\text { 06-benzylguanine }\end{array}$ & & (9\%; 4.5 months) & \\
\hline & Temozolomide+Afatinib & $\begin{array}{l}\text { Grade III diarrhea, skin } \\
\text { toxicity }\end{array}$ & & \\
\hline
\end{tabular}

Table 1b: Chemotherapy with Nitrosoureas and alkalyting agents in mono- and combination-therapy.

\begin{tabular}{|c|c|c|c|c|}
\hline Drug & Agent & Toxicity & $\begin{array}{c}\text { Benefits (PFS-6/Median } \\
\text { OS) }\end{array}$ & Current use \\
\hline $\begin{array}{l}\text { Nitrosoureas \& Alkalyting } \\
\text { agents in monotherapy }\end{array}$ & Carmustine, & $\begin{array}{l}\text { Renal, hepatic, pulmonary } \\
\text { (fibrosis) }\end{array}$ & $\begin{array}{c}\text { (13-17.5\%; 5.1-7.5 } \\
\text { months) }\end{array}$ & \\
\hline \multirow[t]{9}{*}{ (High lipophilicity) } & Lomustine & & & \\
\hline & Nimustine & & (20\%; 6.7 months) & $\begin{array}{l}\text { In combination with } \\
\text { cytarabine or teniposide }\end{array}$ \\
\hline & Enzasturine & $\begin{array}{l}\text { Hematologic (grade III and } \\
\text { IV) Negative efficacity for } \\
\text { Enzasturine }\end{array}$ & (19\%; 7.1 months) & $\begin{array}{l}\text { In combination with } \\
\text { Lomustine }\end{array}$ \\
\hline & & $\begin{array}{l}\text { In combination with } \\
\text { Lomustine }\end{array}$ & & \\
\hline & Fotemustine & & $\begin{array}{c}\text { (20.9-61.0\%; 6-11 } \\
\text { months) }\end{array}$ & \\
\hline & $\begin{array}{l}\text { Fotemustine+ } \\
\text { Temozolomide }\end{array}$ & Major hematologic toxicity & & \\
\hline & Procarbazine & Increase in lymphopenia & (8\%; 3.9-7.2 months) & \\
\hline & $\begin{array}{c}\text { Procarbazine+ } \\
\text { Lomustine+ Vincristine }\end{array}$ & $\begin{array}{l}\text { Grade III or IV hematologic } \\
\text { toxicity of } 26 \%\end{array}$ & (30-38\%; 7.6-7.9 months) & \\
\hline & $\begin{array}{l}\text { Cediranib+ Lomustine+ } \\
\text { antiangiogenic }\end{array}$ & Major hematologic toxicity & (34.5\%; 9.4 months) & \\
\hline
\end{tabular}




\section{Open Access Journal of Surgery}

Table 1c: Chemotherapy with Antiangiogenics in mono- and combination-therapy.

\begin{tabular}{|c|c|c|c|c|}
\hline Drug & Agent & Toxicity & $\begin{array}{c}\text { Benefits (PFS-6/Median } \\
\text { OS) }\end{array}$ & Current use \\
\hline $\begin{array}{c}\text { Antiangiogenics (for } \\
\text { second-line treatment) }\end{array}$ & $\begin{array}{l}\text { Bevacizumab (with } \\
\text { pre-treatment with } \\
\text { Temolozomide) }\end{array}$ & $\begin{array}{l}\text { grades III and IV } \\
\text { toxicities: hypertension, } \\
\text { thromboembolic events, } \\
\text { fatigue }\end{array}$ & $\begin{array}{l}\text { (25-42.6\%; 6.5-9.2 } \\
\text { months) Anti-edema effect, } \\
\text { which allows decreased } \\
\text { use of corticosteroids }\end{array}$ & $\begin{array}{c}\text { FDA approved; not } \\
\text { approved by EMA) } \\
\text { Controversy on } \\
\text { Bevacizumab: treatment } \\
\text { duration }\end{array}$ \\
\hline \multirow[t]{19}{*}{$\begin{array}{l}\text { Monotherapy is not better } \\
\text { than combination therapy }\end{array}$} & $\begin{array}{c}\text { Bevacizumab+ } \\
\text { Carboplatin+ Etoposide+ } \\
\text { Irinotecan+ Temozolomide }\end{array}$ & & & \\
\hline & Bevacizumab+ Irinotecan & & \multirow{2}{*}{ (30-53\%; 6.1-9.7 months) } & \\
\hline & (best combination) & & & \\
\hline & $\begin{array}{l}\text { Bevacizumab+ Irinotecan+ } \\
\text { Cetuximab }\end{array}$ & & (33\%; 7 months) & \\
\hline & $\begin{array}{c}\text { Bevacizumab+ } \\
\text { Carboplatin+ Etoposide }\end{array}$ & & (22\%; 6.9 months) & \\
\hline & Bevacizumab+ Etoposide & & (44.4\%; 10.2 months) & \\
\hline & Bevacizumab+ Ertonilib & & (29\%; 10.3 months) & \\
\hline & Bevacizumab+ Lomustine & & (41-59\%; 11 months) & \\
\hline & $\begin{array}{l}\text { Bevacizumab+ } \\
\text { Fotemustine }\end{array}$ & & $\begin{array}{l}\text { AT SIX-MONTHS: } \quad \text { For } \\
\text { Bevacizumab: (62.1\%; } 7.3 \\
\text { months) }\end{array}$ & \\
\hline & & & $\begin{array}{l}\text { For Fotemusine: ( } 73.3 \% ; \\
\quad 8.7 \text { months) }\end{array}$ & \\
\hline & & & $\begin{array}{c}\text { AT NINE-MONTHS: } \\
\text { For Bevacizumab: } 37.9 \% \text {; } \\
7.3 \text { months) }\end{array}$ & \\
\hline & & & $\begin{array}{l}\text { For Fotemusine: ( } 46.7 \% \text {; } \\
\qquad 8.7 \text { months) }\end{array}$ & \\
\hline & Aflibercept & Asthenia; Hypertension & $-7.70 \%$ & \\
\hline & $\begin{array}{l}\text { Met+EVGFR2+ RET } \\
\text { inhibitor+ XL-184 } \\
\text { (Cabozantinib) }\end{array}$ & Fatigue & $(21-25 \%)$ & \\
\hline & & Hypophosphatemia & & \\
\hline & & Increased lipases & & \\
\hline & & Migraines & & \\
\hline & & Lymphopenia & & \\
\hline & & Convulsions & & \\
\hline
\end{tabular}

Table 1d: Chemotherapy with EGFR inhibitors in mono- and combination-therapy.

\begin{tabular}{|c|c|c|c|c|}
\hline Drug & Agent & Toxicity & $\begin{array}{c}\text { Benefits (PFS-6/Median } \\
\text { OS) }\end{array}$ & Current use \\
\hline \multirow{6}{*}{$\begin{array}{c}\text { EGFR Inhibitors } \\
\text { (Inconclusive results } \\
\text { whether in mono-or } \\
\text { combination therapy) } \\
\text { Most frequent mutation } \\
\text { insensitive }\end{array}$} & Gefitinib & & No responses & \\
\hline & & & & \\
\hline & Afatinib & $\begin{array}{l}\text { Grade III diarrhea, skin } \\
\text { toxicity }\end{array}$ & $(3 \%)$ & \\
\hline & Ertolinib & & (12\%; 7 months) & Usual dose is inadequate \\
\hline & Everolimus+ Gefitinib & & (2.6 months) & \\
\hline & $\begin{array}{l}\text { Ertolinib+ Gefitinib+ } \\
\text { Sirolimus }\end{array}$ & & $-25 \%$ & \\
\hline
\end{tabular}




\section{Open Access Journal of Surgery}

\begin{tabular}{|c|c|c|c|c|}
\hline & Ertolinib+ Carboplatin & $\begin{array}{c}\text { Grades III and IV } \\
\text { fatigue, leucopenia, } \\
\text { thrombocytopenia, rash }\end{array}$ & (14\%; 30 weeks) & \\
\hline $\begin{array}{c}\text { More sensitive to } \\
\text { mutations }\end{array}$ & Lapatinib (HKI-272) & & & \\
\hline
\end{tabular}

Table 1e: Chemotherapy with other agents in mono- and combination-therapy.

\begin{tabular}{|c|c|c|c|c|}
\hline Drug & Agent & Toxicity & $\begin{array}{c}\text { Benefits (PFS-6/Median } \\
\text { OS) }\end{array}$ & Current use \\
\hline Other Agents & Cilengitide & Minor & (12-15\%; 9.9 months) & Discouraging results \\
\hline EGFR \& PDGFR & & & & Discouraging results \\
\hline MTOR antagonist & & & & Discouraging results \\
\hline $\begin{array}{c}\text { Phospholinositide 3-kinase } \\
\text { antagonist }\end{array}$ & & & & Discouraging results \\
\hline $\begin{array}{c}\text { Histone deacetylase } \\
\text { antagonist }\end{array}$ & & & Discouraging results \\
\hline $\begin{array}{c}\text { Farnesyltransferase } \\
\text { antagonist }\end{array}$ & & & & \\
\hline
\end{tabular}

a. Research: As of 2014, there were 22 various drugs with potent anti-glioblastoma activity, including the combination of Irinotecan and statins. Laboratory research using genetically engineered stem cells to target GBs in mice also showed promise [2-4].

b. MicroRNA: RNA interference, usually microRNA, is being studied in tissue culture, pathology specimens and in preclinical animal studies. MicroRNA (mi-RNA)-screening of plasma is used to determine the prognosis of GB $[5,6]$.

c. Immunotherapy: The immunotherapeutic approach to GB has been studied in a number of Phase I and II trials with encouraging results. Phase III with anti-EGFR vaccines are currently under way, but results are not yet available. A review of all the immunotherapy trials suggests that vaccination is safe in terms of side effects and effectiveness.

Immunotherapy using dendritic cell (DC) vaccination in recurrent GBs has been assessed in 12 studies (including four with a control arm). In seven of the studies, the immunotherapy arm experienced better OS results. In 10 of the studies, the median OS spanned the range 38-138 weeks. The best results for median OS were reported for clinical trials that had in common vaccination given immediately after surgery [7-12]. GB relapse is attributed to the recurrence and persistence of tumor stem cells (TSC). In this regard, two clinical trials are noteworthy:

i. Tumor B-cell Hybridoma Vaccine: In a small trial, a tumor B-cell hybridoma vaccine against tumor stem cells elicited a specific tumor immune reaction, thus enhancing an immune response to the disease [13-21]; and

ii. Tests of different EGFR signaling patterns: Larger trials, including tests of different EGFR signaling patterns and their relationship to tumor stem cells are being conducted. However, the test of Rindopepimut failed in a phase III trial in 2016. While several drugs have failed in extending survival, the new immunotherapies including CAR-T cells immunotherapies such as Pembrolizumab (Keytruda) and Nivolumab (Opdivo) have changed the landscape with initial promising results in brain cancer. Other immunotherapeutic and vaccine-type approaches are at different stages of development, but conclusive results are not yet available.

d. Adjuvant therapy: Trials of adjuvant therapy using autologous-loaded dendritic cells and antigen-presenting cells have reported that PFS and OS increase in patients on first-line treatment with recurrent GB.

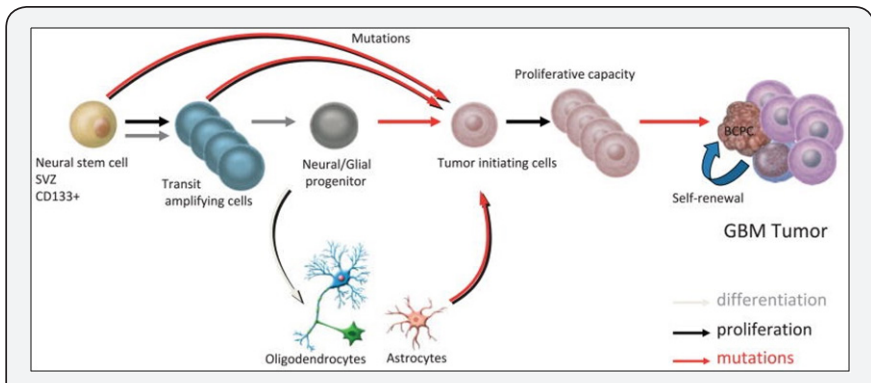

Figure 4: Showing the development of a glioblastoma from a neural stem cell.

e. Gene therapy: Gene therapy is a promising approach for fighting cancers, including brain cancer. Unlike current conventional cancer treatments, gene transfer has the potential to selectively kill cancer cells while leaving healthy cells unharmed. Over the past two decades, significant advances have been made in gene transfer technology (GTT) and the field has matured to the point of clinical and commercial feasibility [13]. Figure 4 illustrates the formation of a GB from a neural stem cell.

\section{i. Advances include:}

a) Vector construction: This is the gene delivery vehicle (GDV);

b) Vector producer cell efficiency; 


\section{c) Scale-up processes;}

d) Preclinical models for target diseases; and

e) Regulatory guidance: This regards clinical trial design, including endpoint definitions and measurements.

In one such approach in 2005, researchers at UCLA reported a long-term survival benefit in an experimental brain tumor animal model. Subsequently, in preparation for human clinical trials, the technology was further developed by Tocagen. Since 2010, Toca 511 is under clinical investigation in a Phase I trial for the potential treatment of recurrent high-grade glioma including GB and anaplastic astrocytoma. The study was due to be completed in July 2016. As of January 2016, six different trials of Toca 511 have been registered. Updates on a meta analysis of Toca 511 are highly anticipated.

f. Intranasal drug delivery: Intranasal (or direct noseto-brain) drug delivery (INDD) is being explored as a means to achieve higher, and hopefully more effective, drug concentrations in the brain. A clinical phase I/II study with GB patients in Brazil investigated the natural compound perillyl alcohol for intranasal delivery as an aerosol [14-18]. Because the results of this trial were encouraging, a similar trial was initiated in 2016 in the U.S. [14-16].

g. Anopheles mosquito transmission of brain tumors: Some authors have noted that anophele mosquitoes may be able to transmit brain tumors [17]. Further, based on the malaria experience, another researcher has also suggested that disrupting cell mitoses may provoke cancer selfdestruction [18].

h. Nanotechnology: A series of recent articles has explored the capabilities of nanotechnology to penetrate the BPBs to deliver therapeutic drugs to a variety of brain tumors, including GBs, at the right location, at the right time, and in the right dose regimen [19-22].

\section{Summary and Conclusion}

Glioblastoma (or glioblastoma multiform) is the most common primary brain tumor in adults. It remains an unmet need in oncology. Most of the known treatments cannot eradicate all tumor cells (surgery is often insufficient given the diffuse nature of the disease; chemotherapy has major limitations because most drugs cannot cross the BBB, and penetration into brain cells is limited). In addition, the cells in brain tumors are greatly heterogeneous, which limits the treatment efficacy and explains the high rate of progression of the disease. Disease recurs in almost all patients, and most patients will not be candidates for new surgery or a new course of irradiation so that therapeutic options are limited [23-29].

I have discussed the various treatment options whether singly or in combination. I have also summarized the many clinical trials conducted so far and recapitulated their main characteristics: benefits (if any), toxicities and current dose regimen for various chemotherapy strategies employing firstline Temozolomide either alone or in combination with other drugs; nitrosoureas and alkalyting agents; antiangiogenic agents; epidermal growth factor receptor gene inhibitors; and several other agents. The trials have reported only modest increases in PFS and minimal or even doubtful increases in overall survival [30-34].

In present-day practice, it is recommended that treatment of recurrent glioblastoma be individualized according to several factors: performance status; age; tumor histology; biomarkers; possibility for repeat surgery; time to recurrence; and response to prior treatment $[35,36]$. It is also recommended that patients be enrolled into well-designed clinical trials to maximize their clinical benefits. Research into these and other treatment options is ongoing including but not limited to: microRNA; immunotherapy; adjuvant therapy; gene therapy; stem cell therapy, and intra-nasal drug delivery. It is too early to report definitely on their corresponding benefits and associated risks.

\section{References}

1. Fymat AL (2017) Surgical and Non-Surgical Management and Treatment of Glioblastoma: I. Primary Tumors. Open Access Journal of Surgery (in press).

2. Ghebeh H, Bakr MM, Dermime S (2008) Cancer stem cell immunotherapy: The right bullet for the right target. Hematology/ oncology and stem cell therapy 1(1): 1-2.

3. Moviglia GA, Carrizo AG, Varela G, Gaeta CA, Paes De Lima A, et al (2008) Preliminary report on tumor stem cell/B cell hybridoma vaccine for recurrent glioblastoma multiform. Hematology/oncology and stem cell therapy 1(1): 3-13.

4. Stuckey D, Hingtgen S, Karaka N, Rich B, Shah K (2015) Engineering toxin-resistant therapeutic stem cells to treat brain tumors. Stem Cells. AlphaMed Express 33(2): 589-600.

5. Henriksen M, Johnsen KB, Andersen H, Holm M, Pilgaard L, et al. (2014) MicroRNA expression signatures determine prognosis and survival in glioblastoma Multiform-a systematic overview. Molecular Neurobiology 50(3): 896-913.

6. Møller HG, Rasmussen AP, Andersen HH, Johnsen KB, Kasper B, et al. (2013) A Systematic review of microRNA in glioblastoma multiform: Micro-modulators in the mesenchymal mode of migration and invasion. Molecular Neurobiology 47(1): 131-144.

7. Yang, Guo G, Niu XY, Liu J (2015) Dendritic cell-based immunotherapy treatment for glioblastoma multiform. Biomed Res Int 717530.

8. Fymat AL (2017) Immunotherapy: An emergent anti-cancer strategy. J Cancer Prev Curr Res 7(3): 1-4.

9. Fymat AL (2017) Synthetic immunotherapy with chimeric antigen receptors. J Cancer Prev Curr Res 7(5): 1-3.

10. Fymat AL (2017) Immunotherapy of brain cancers and neurological disorders. J Cancer Prev Curr Res.

11. Hofman FM, Stathopoulos A, Kruse CA, Chen TC, Schijns VE (2010) Immunotherapy of malignant gliomas using autologous and allogeneic issue cells. Anticancer Agents in Medicinal Chemistry 10(6): 462-470.

12. National Cancer Institute (2015) With Immunotherapy, glimmers of progress against glioblastoma. National Cancer Institute. 
13. Fulci G, Chiocca EA (2007) The status of gene therapy for brain tumors. Expert Opinion on Biological Therapy 7(2): 197-208.

14. Pardeshi CV, Belgamwar VS (2013) Direct nose to brain drug delivery via integrated nerve pathways bypassing the blood-brain barrier: An excellent platform for brain targeting. Expert Opinion in Drug Delivery 10(7): 957-972

15. Peterson A, Bansal A, Hofman F, Chen TC, Zada G (2014) A systematic review of inhaled intranasal therapy for central nervous system neoplasms: An emerging therapeutic option. Journal of Neurooncology 116(3): 437-446.

16. Van Woensel M, Wauthoz N, Rosière R, Amighi K, Mathieu V, et al. (2013) Formulations for intranasal delivery of pharmacological agents to combat brain disease: A new opportunity to tackle GBM?. Cancers (Basel) 5(3): 1020-1048.

17. Lehrer S (2010) Anopheles Mosquito Transmission of Brain Tumor. Medical Hypotheses 74(1):167-168.

18. Fymat AL (2017) Disrupting Cell Mitoses to Provoke Cancer SelfDestruction, Cancer Therapy \& Oncology. Int J 5(1): 1-3.

19. Fymat AL (2016) Nanotechnology and cancer. J Cancer Prev Curr Res 2016, 5(6):1-7.

20. Fymat AL (2017) On cancer electro-and nano-chemotherapy. J Cancer Prev Curr Res 7(2):1-4.

21. Fymat AL (2017) Nanochemotherapy: An emergent anti-cancer modality. Global J Nanomed 1(1): 5.

22. Fymat AL (2017) Nanooncology: Perspective on promising anti-tumor therapies. J Tumor Medicine \& Prevention 1(1): 1-10.

23. Fymat AL (2016) Recent research developments in anti-cancer therapy. J Cancer Prev Curr Res 5(2): 1-2.

24. Fymat AL (2016) The long quest for cancer cures. J Cancer Prev Curr Res 6(2): 1-3.

25. Fymat AL (2017) Nanoneurology: Drug delivery across the brain protective barriers. J Nanomed Res 5(1): 1-4.
26. Fymat AL (2017) Therapeutics delivery behind, through and beyond the blood brain barrier. Open Access Journal of Surgery 5 (1): 19.

27. Hayden EC (2010) Genomics boosts brain-cancer work. Nature 463(7279): 278.

28. Kuehn BM (2010) Genomics Illuminates a Deadly Brain Cancer. JAMA 303 (10):925-7.

29. Ohgaki H, Kleihues P (2009) Genetic alterations and signaling pathways in the evolution of gliomas. Cancer Science 100(12): 2235-2241.

30. Verhaak RGW, Hoadley KA, Purdom E, Wang V, Qi Y, et al. (2010) Integrated genomic analysis identifies clinically relevant subtypes of glioblastoma characterized by abnormalities in PDGFRA, IDH1, EGFR, and NF1. Cancer Cell. 17(1): 98-110.

31. Krex D, Klink B, Hartmann C, Von Deimling A, Pietsch T, et al. (2007) Long-term survival with glioblastoma multiform. Brain $130(10)$ : 2596-2606.

32. Stummer W, Pichlmeier U, Meinel T, Wiestler OD, Zanella F, et al. Ala-Glioma Study Group (2006) Fluorescence-guided surgery with 5-aminolevulinic acid for resection of malignant glioma: A randomized controlled multicenter phase III trial. The Lancet Oncology 7(5): 392-401.

33. Young RM, Jamshidi A, Davis G, Sherman JH (2015) Current trends in the surgical management and treatment of adult glioblastoma. Annals of Translational Medicine 3(9): 121.

34. Khasraw M, Ameratunga MS, Grant R, Wheeler H, Pavlakis N (2014) Antiangiogenic therapy for high-grade glioma. The Cochrane database of systematic reviews.

35. Bleeker FE, Molenaar RJ, Leenstra, Sieger (2012) Recent advances in the molecular understanding of glioblastoma. Journal of NeuroOncology 108(1): 11-27.

36. Van Meir EG, Hadjipanayis CG, Norden AD, Shu HK, Wen PY, et al. (2010) Exciting new advances in neuro-oncology: The avenue to a cure for malignant glioma. CA: A Cancer Journal for Clinicians 60(3): 166-193.

\section{Your next submission with Juniper Publishers will reach you the below assets}

- Quality Editorial service

- Swift Peer Review

- Reprints availability

- E-prints Service

- Manuscript Podcast for convenient understanding

- Global attainment for your research

- Manuscript accessibility in different formats

( Pdf, E-pub, Full Text, Audio)

- Unceasing customer service

Track the below URL for one-step submission https://juniperpublishers.com/online-submission.php 